prof. zw. dr hab. inż. Ryszard JANIKOWSKI

Państwowa Wyższa Szkoła Zawodowa w Oświęcimiu

e-mail: ryszard.janikowski@gmail.com

DOI: $10.15290 /$ ose.2016.03.81.05

\title{
POLITYKA SPÓJNOŚCI JAKO DETERMINANTA PRZYSPIESZENIA PERCEPCJI KULTURY ZRÓWNOWAŻONEGO ROZWOJU W POLSCE
}

\begin{abstract}
Streszczenie
Koncepcja zrównoważonego rozwoju jest osią cywilizacji euroatlantyckiej. Polski system instytucjonalny państwa był i jest mało aktywny w upowszechnianiu i wdrażaniu kultury zrównoważonego rozwoju. W odniesieniu do innych państw unijnych jest on opóźniony w procesie: promowania, budowania i aktywnego kształtowania. We wszystkie cele działania Unii Europejskiej jest wpisana istota zrównoważonego rozwoju. Tym samym kultura polityczna Wspólnot Europejskich dzięki polityce spójności determinująco oddziałuje na kultury narodowe. W ten sposób, co udokumentowano w artykule, zachodzi bardzo korzystny proces, który powoduje polityka spójności i wdrażanie kultury zrównoważonego rozwoju w Polsce.
\end{abstract}

Słowa kluczowe: system instytucjonalny państwa, polityka spójności, zrównoważony rozwój

\section{COHESION POLICY AS A DETERMINANT OF PERCEPTION CULTURE OF SUSTAINABLE DEVELOPMENT IN POLAND}

\section{Summary}

The concept of sustainable development is central for Euro-Atlantic civilization. Polish institutional system of the wasn't and isn't active in promoting and implementing sustainable development culture. In relation to other EU countries it is delayed in the process of promoting, building and actively shape. In all the objectives of the EU's action is inscribed sustainability. Thus, the political culture of the European Communities through cohesion policy determining impact on national cultures. Thus, as documented in the work, there is a very positive process, caused by cohesion policy, the implementation of sustainable development culture in Poland.

Key words: governmental institutional system, cohesion policy, sustainable development

JEL: Q001; Q56; J58

\section{Wstęp}

W raporcie Polska 2050 Komitetu Prognoz „Polska 2000 Plus” Polskiej Akademii Nauk [Kleiber, Kleer, Wierzbicki, Galwas, Kuźnicki, Sadowski, Strzelecki, 2011] stwier- 
dza się, że konieczne jest przełamanie długookresowych i skumulowanych barier w naszym systemie kulturowym, mających niemal powszechny charakter, a przy tym rzadko uświadamianych sobie przez Polaków. Podkreśla się w nim, że jest to czynnik determinujący rozwój Polski oraz pozwalający na zmniejszenie dystansu cywilizacyjnego, jaki dzieli nasz kraj od najbardziej rozwiniętych państw świata.

Najważniejsza, a jednocześnie „niewidzialną” barierą wydaje się być ta, która wynika zarówno z niepełnego wpisania do polskiej kultury całokształtu kultury zrównoważonego rozwoju (sustainable development) [Janikowski, 2011], jak i błędnego pojmowania idei zrównoważoności, ale również ze stanowisk części elit naukowych i politycznych ortodoksyjnie jej przeciwnych oraz niemobilności i kulturowego zapóźnienia wywodzącego się z czasu socjalistycznego izolacjonalizmu [Frysztacki, Sztompka, 2012]. Koncepcja zrównoważonego rozwoju powinna być i już jest osią cywilizacji euroatlantyckiej, stąd w tym świetle zasadnicze wydaje się pytanie, jakie są determinanty przyspieszenia percepcji i upowszechnienia kultury oraz istoty zrównoważonego rozwoju w Polsce. Stwierdza się, co udokumentowano w artykule, że bardzo istotna determinantą przyspieszenia upowszechnienia kultury zrównoważonego rozwoju w Polsce była i jest unijna polityka spójności. Jednocześnie celem opracowania jest wskazanie czynników wpływających na poszerzenie i pogłębienie kultury zrównoważonego rozwoju [Culture: Fourth Pillar of Sustainable Development, 2014].

\section{Zrównoważony rozwój}

W kontekście ogólnego rozwoju cywilizacyjnego naszej ery szczególnego znaczenia nabiera fundamentalny, choć ciagle jeszcze rozwijający się, element kultury, jakim jest idea zrównoważonego rozwoju (sustensywnego) Juknys, 2012; Janikowski, 2010; Janikowski, Krzysztofek, 2009]. Conditio sine qua non tego, aby koncepcja zrównoważonego rozwoju mogła być w pełni wdrożona, jest jej wpisanie w kulturę wszystkich społeczeństw, w tym także polskiego. Jednocześnie system instytucjonalny państwa polskiego nadal nie wywiązuje się ze swojego zadania, jakie wprost wynika z artykułu 5. Konstytucii Rzecsypospolitej Polskiej: Rzeczpospolita Polska strzeże niepodlegtości i nienaruszalności swojego terytorium, zapewnia wolności i prawa człowieka $i$ obywatela oraz bezpieczeństwo obywateli, strzeże dziedzictwa narodowego oraz zapewnia ochrone środowiska, kierujac sie zasada zrównoważonego rozwoju.

Przyjęto, uproszczony na potrzeby tej analizy, cybernetyczny model systemu instytucjonalnego państwa (SIP) (rysunek 1.), który powinien generować co najmniej pięć strumieni sygnałów. Niektóre z nich powinny być permanentne, a inne statycznie trwałe. W ramach przyjętych założeń SIP jako czarna skrzynka powinien mieć na wyjściu cztery różne, aczkolwiek współzależne sygnały wyjściowe, które syntetycznie określono jako:

- pochodne, w odniesieniu do konstytucji, prawo (ustanowione);

- $\quad$ instytucję centralną do spraw zrównoważonego rozwoju (jedną trwała);

- $\quad$ dokument(y) strategiczny(e) określający(e) strategie zrównoważonego rozwoju Polski (jeden dokument strategiczny, sporadycznie modyfikowany); 
- $\quad$ relacje z agendami Unii Europejskiej w płaszczyźnie sustainable development (wypełnianie wspólnotowych reguł, w tym ustanowienia narodowej strategii zrównoważonego rozwoju);

- $\quad$ edukację, począwszy od edukacji szkolnej, aż do edukacji wyższej wszystkich kierunków studiów (wpisanie do systemu edukacyjnego upowszechniania co najmniej elementarnego zarysu koncepcji zrównoważonego rozwoju).

RYSUNEK 1.

\section{Model cybernetyczny systemu instytucjonalnego państwa}

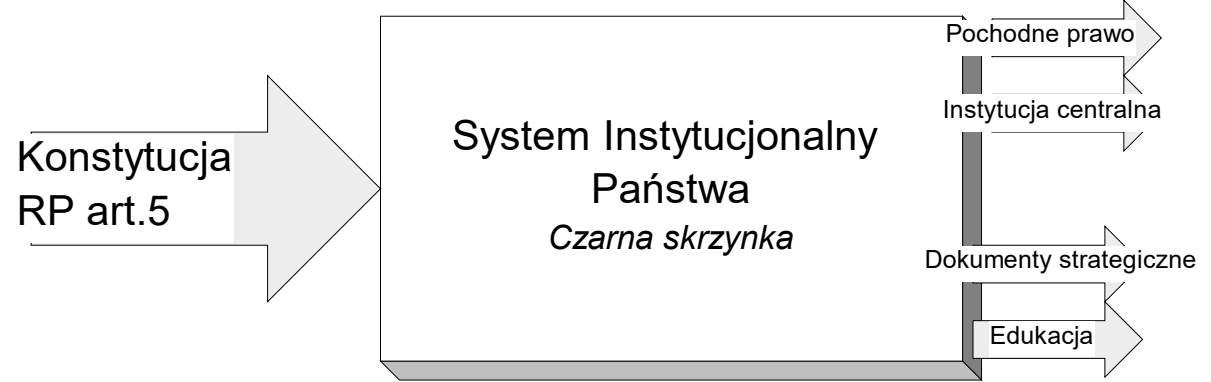

Źródło: opracowanie własne.

\subsection{Pochodne prawo}

Polski ustawodawca Ustawa z dnia 29 sierpnia 1997 roku dokonał zmiany treści preambuły Ustany z dnia 31 stycznia 1981 roku o ochronie $i$ ksztaltowaniu środowiska [Dz.U. 1981, $\mathrm{nr} 3$, poz. 6 z póź. zm.] na poniższą.

Rzeczpospolita Polska, kierując się zasadą zrównoważonego rozwoju, oznaczającą dążenie do:

- zachowania możliwości odtwarzania się zasobów naturalnych;

- $\quad$ racjonalnego użytkowania zasobów nieodnawialnych i zastępowania ich substytutami;

- ograniczania uciążliwości dla środowiska i nieprzekraczania granic wyznaczonych jego odpornością;

- zachowania różnorodności biologicznej;

- zapewnienia obywatelom bezpieczeństwa ekologicznego;

- $\quad$ tworzenia podmiotom gospodarczym warunków do uczciwej konkurencji w dostępie do ograniczonych zasobów i możliwości odprowadzania zanieczyszczeń zapewnia ochronę i racjonalne kształtowanie środowiska stanowiącego dobro ogólnonarodowe oraz tworzy warunki sprzyjające urzeczywistnianiu prawa obywateli do równoprawnego korzystania z wartości środowiska. 
Kierując się powyższym, uznaje się za niezbędne:

- $\quad$ ustanowienie środków prawnych zapewniających użytkowanie środowiska zgodnie $z$ interesem publicznym;

- określenie obowiązków organów państwowych, samorządowych, podmiotów gospodarczych i innych jednostek organizacyjnych, a także organizacji społecznych i zawodowych;

- $\quad$ ochronę środowiska przez każdego obywatela oraz rozwijanie świadomości społecznej w celu powszechnego wypełniania tego obowiązku [Ustawa z dnia 29 sierpnia 1997 roku..., 1997, preambuła].

Wprowadzenie tego zapisu oznaczało wypełnienie treścią artykułu 5 Konstytucji Rz̨eczypospolitej Polskiej. Jednocześnie analiza powyższego tekstu jednoznacznie wskazuje, że w roku 1997 polski ustawodawca rozumiał przez kategorię zrównoważony rozwój tylko bardzo szeroko pojętą ochronę i racjonalne kształtowanie środowiska. Dopiero po upływie kilku lat miała miejsce zmiana definicyjna tej kategorii, co znalazło swój wyraz w artykule 3.50 Ustawy z dnia 27 kwietnia 2001 roku Prawo ochrony środowiska [Dz.U. 2001, nr 62, poz. 627; tekst ujednolicony]. Ustawodawca bowiem podał w tejże ustawie definicję zrównoważonego rozwoju, a mianowicie: rozumie się przez to taki rozwój społecznogospodarczy, w którym następuje proces integrowania działań politycznych, gospodarczych i społecznych, z zachowaniem równowagi przyrodniczej oraz trwałości podstawowych procesów przyrodniczych, w celu zagwarantowania możliwości zaspokajania podstawowych potrzeb poszczególnych społeczności lub obywateli zarówno współczesnego pokolenia, jak i przyszłych pokoleń [Ustawa z.dnia 27 kwietnia 2001 roku..., 2001, art. 3.50].

Tak określony rozwój w istocie dobrze oddaje treści zrównoważonego rozwoju, jednakże nie ogranicza to kłopotów definicyjno-lingwistycznych związanych z tą kategoria cywilizacyjna. Innym, długo trwającym zamieszaniem znaczeniowym było stosowanie w Polsce terminu ekorozwój. Z kolei, w pracy K.H. Baek i N. Ko [Baek, Ko, 2015] wskazano inny, całkiem skrajny, przykład dotyczący tłumaczenia, który przyczynił się do wprowadzenia kategorii wzrostu, zamiast rozwoju. Od początku lat dziewięćdziesiątych dwudziestego wieku Wspólnoty Europejskie w sposób jednoznaczny traktowały ideę zrównoważonego rozwoju (sustainable development). Została ona wprowadzona jako zasada konstytuująca działania rozwojowe Wspólnot do Traktatu z. Maastricht. Tym samym znalazło to swój wyraz w artykule 2.3 Traktatu o Unii Europejskiej i Traktatu ustanawiajacego W spólnote Europejskeq podpisanego w Lizbonie w roku 2007. Oznaczało i oznacza to, że idea zrównoważonego rozwoju stała się osiowym elementem cywilizacji unijno-europejskiej, jak i trwała podstawą europejskiego myślenia strategicznego [Korkut, 2008] oraz wszelkich działań pragmatycznych Komisji Europejskiej, Rady Europejskiej i Parlamentu Europejskiego [jiricka, Pröbstl, 2013].

Rzeczpospolita Polska, stając się współtworzącym elementem Wspólnot Europejskich, przyjęła także cytowany Traktat o Unii Europejskiej i Traktat ustanawiajacy Wspólnote Europejska. Z uwagi na takie, a nie inne tłumaczenie Traktatu na jezzyk polski pojawiła się istotna formalno-prawna konfuzja, gdyż obie wersje są równoprawne. Pokazuje to zestawienie dwóch wersji językowych artykułu 2.3 Traktatu (tabela 1.), który definiuje istotę i zakres rozumienia kategorii zrównoważony rozwój w ramach Unii Europejskiej. 
TABELA 1.

Polska i angielska wersja językowa artykułu 2.3. Traktatu o Unii Europejskiej i Traktatu ustanawiającego Wspólnotę Europejską

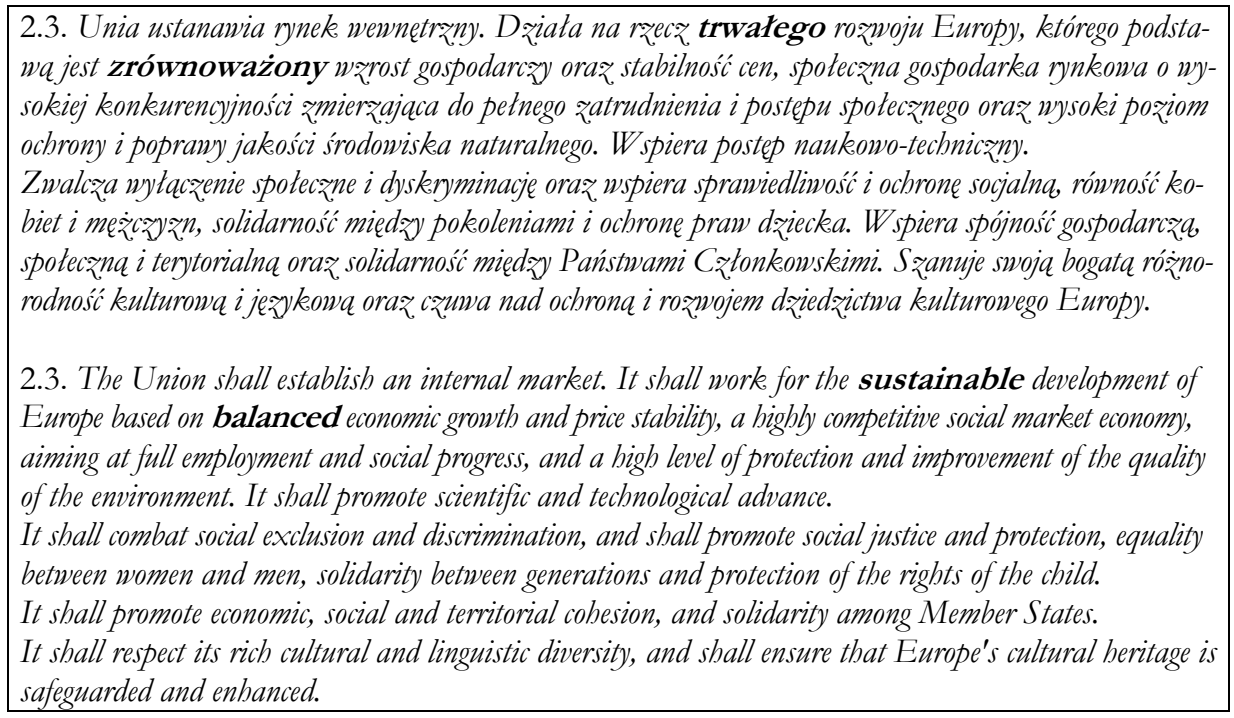

Źródło: [Traktat z. Liz̧bony..., 2007].

Wskazane powyżej kwestie powodowały (i nadal powoduja), że w przestrzeni terminologicznej i definicyjnej, a tym samym w komunikowaniu się, jak i budowaniu kultury nie mamy jednolitości lingwistycznej (zrównoważony, trwały, zrównoważony i trwały, sustensywny).

\subsection{Instytucja centralna}

Na szczeblu rządowym efemerycznie pojawia się i znika instytucja, której celem jest kształtowanie zrównoważonego rozwoju w Polsce [Janikowski, 2005]. Różne jest jej umocowanie prawne, rozmaity zakres działania i skład osobowy. W roku 1994 powołano Krajową Komisję do spraw Ekorozwoju, która została rozwiązana w roku 1997. Następnie w roku 1998 powołano Komitet Rady Ministrów Polityki Regionalnej i Zrównoważonego Rozwoju, który przestał istnieć wraz z rozwiązaniem innych, stałych komitetów Rady Ministrów. Kolejno w roku 2002 powołano organ wewnętrzny Rady Ministrów, czyli Radę do spraw Zrównoważonego Rozwoju. Rada ta została powołana zarządzeniem prezesa Rady Ministrów numer 107 z dnia 11 września 2002 roku i rozpoczęła swoją działalność, po upływie prawie roku, w maju 2003 roku. Z kolei zarządzeniem numer 83 Prezesa Rady Ministrów z dnia 16 listopada 2010 roku nastąpiło zniesienie Rady do spraw Zrównoważonego Rozwoju.

Z odpowiedzi ministra środowiska Tomasza Podgajniaka (z 2005 roku) - z upoważnienia prezesa Rady Ministrów - na interpelację nr 10304 w sprawie działalności Rady 
do spraw Zrównoważonego Rozwoju dowiadujemy się, że przeprowadzona analiza kosztów funkcjonowania Rady pozwala stwierdzic, że konieczne jest rapewnienie rocznie sumy w przedriale 60 000-90 000 zt, z.crego:

- na utryymanie sekretariatu Rady okoto 5000 zk; jeśli sekretariat bedzie prowadzony w ramach dodatkonych zadan przez pracownikón MŚ lub GIOŚ (opcjonalnie przez pracowników Ministerstwa Gospodarki) lub 30 000 zt; jeśli zostanie utworzone dodatkowe stanowisko asystenta,

- na wspótprace miédzynarodowa 30000 zt,

- na organizacje stron internetonych 10000 ₹k, jeśli bedzie to zadanie zlecane przez sekretariat,

- na zlecanie elespertyz i opinii 30000 ž,

- na zwrot delegacji cz̧onkom Rady spoza Warszany 3000 zt [Odpowiedzi Ministra Środowiska..., 2015]

Choćby te cytowane wielkości środków na działalność Rady do spraw Zrównoważonego Rozwoju wskazują, że w ramach polskiego systemu instytucjonalnego miało to znaczenie marginalne i absolutnie nieznaczące. Możliwości oddziaływania, upowszechniania i/lub pogłębiania istoty zrównoważonego rozwoju tejże Rady były całkowicie fasadowe. W obliczu upowszechniania i implementowania fundamentalnej koncepcji cywilizacyjnej w Polsce kolejnym paradoksem jest fakt, że w październiku 2014 roku, Wicepremier Rzeczypospolitej Polskiej, Janusz Piechociński powołał Społeczną Radę do spraw Zrównoważonego Rozwoju Energetyki, której najważniejszym zadaniem będzie opracowywanie propozycji i koncepcji rozwiązań systemowych w obszarze polskiej energetyki w kontekście unijnych i międzynarodowych uwarunkowań. System instytucjonalny państwa polskiego uruchamia działania, które w istocie swojej moga determinować niezrównoważony rozwój naszego kraju [Ciepiela, 2014].

\subsection{Dokument(y) strategiczny(e) szczebla centralnego}

Żaden z prezesów Rady Ministrów Rzeczypospolitej Polskiej nie wykorzystywał ani agend rzadowych, ani powoływanych przez siebie instytucji centralnych do tworzenia strategii i do kierunkowania zrównoważonego rozwoju Polski. Co prawda, rząd, na którego czele stanął Jerzy Buzek, opracował w roku 2000 dokument Polska 2025 - Dlugookresowa strategia trwatego $i$ zrómnoważonego rozwoju, lecz kolejny rząd, opozycyjny do poprzedniego, pod kierunkiem Leszka Millera przyjął, że takowy dokument nie istnieje. Z kolei, rząd Donalda Tuska rozpoczał przygotowywanie dokumentu strategicznego Polska 2030 - Trzecia fala nowoczesności. D tugookresowa strategia rozwoju kraju. Istota propozycji Polska 2030 był projekt cywilizacyjny zorientowany na przyszłość, na co najmniej o jedno pokolenie więcej niż to, które aktualnie odgrywa aktywną rolę w określaniu celów rozwojowych. Dokument przygotowany przez Zespół Doradców Strategicznych Premiera Rzeczypospolitej Polskiej pod kierunkiem Ministra Michała Boniego jednak „porzucono" i nie dokończono, a tym samym nie stał się wiodącym dokumentem strategicznym wygenerowanym przez SIP jako odpowiedź na wypełnianie treścią istoty konstytucyjnej zasady zrównoważonego rozwoju. 
W końcu należy dodać, że Polska jest jedynym państwem współtworzącym Unię Europejska, które nie posiada narodowej strategii zrównoważonego rozwoju [ESDN, European Sustainable Development Network].

\subsection{Edukacja}

Podstawowy paradygmat współczesności powinien być znany przez wszystkich wykształconych ludzi [Janikowska, 2007], w tym także studiujących na wyższych uczelniach polskich [Janikowski, 2006]. Przeprowadzona analiza przedmiotów wykładanych na kilkunastu uczelniach publicznych i prywatnych (uniwersytety, akademie ekonomiczne, politechniki) zaprezentowana na konferencji Edukacja dla ekorozwoju (2005) jednoznacznie wskazuje, że tylko na jednej jest przedmiot zrównoważony rozwój. Wykładane są różne przedmioty z zakresu ochrony środowiska, takie jak: zarządzanie środowiskowe, zarządzanie środowiskiem, ubezpieczenia ekologiczne, systemy ISO 14000/EMAS, podstawy ekologii i wiele podobnych, aczkolwiek o zróżnicowanym i odmiennym zakresie treści. Jedynie w niektórych z nich jest sygnalizowane zagadnienie nowego paradygmatu rozwoju, jednakże w bardzo skromnym i niewystarczającym zakresie. Potwierdza to także analiza wszystkich, opublikowanych standardów kształcenia. Na kierunkach, takich jak: politologia, geografia, geodezja i kartografia oraz inżynieria środowiska, rozwój zrównoważony pojawia się w ramach różnych przedmiotów. Tylko na kierunku ochrona środowiska jest przedmiot kierunkowy zagrożenia cywilizacyjne i zrównoważony rozwój.

Z badań przeprowadzonych przez firmę iTTi wynika, iż obecnie brakuje dokumentu określającego kierunek edukacji dla zrównoważonego rozwoju w Polsce. Z kolei, Narodowa Strategia Edukacji Ekologicznej przez Edukacje do Zrównoważonego Rozwoju jest dokumentem już ponad dziesięcioletnim. Wskazuje się także, że definicja rozwoju zrównoważonego jest trudna do zrozumienia przez respondentów, zwłaszcza nauczycieli i uczniów, gdyż jak sami oni uznali, samo zagadnienie jest bardzo złożone. Spośród studentów, wśród których zostało przeprowadzone badanie ankietowe, 29\% nigdy wcześniej nie spotkało się z kategorią rozwoju zrównoważonego, jedynie 10\% znało dobrze to pojęcie. Jeszcze niższy poziom znajomości idei zrównoważonego rozwoju wystapił wśród uczniów szkół podstawowych, gimnazjów czy szkół ponadgimnazjalnych. W'́ród nauczycieli kategoria ta najlepiej była znana w gronie osób związanych z edukacja przyrodniczą [Ekespertyza dotyczqca Edukacji..., 2012]. Warto dodać, że zgodnie z cytowana ustawą Prawo ochrony środowiska, w artykule 77.1. stwierdza się, że problematykę ochrony środowiska i zrównoważonego rozwoju uwzględnia się w podstawach programowych kształcenia ogólnego dla wszystkich typów szkół [Ustawa z.dnia 27 kwietnia 2001 roku..., 2001, art. 77.1].

\subsection{Ocena działania SIP}

System instytucjonalny polskiego państwa był i jest mało aktywny w upowszechnianiu i wdrażaniu zrównoważonego rozwoju. W odniesieniu do innych państw unijnych czy też Norwegii [Zimny, Zawieja-Żurowska, 2015] jest on opóźniony w procesie: pro- 
mowania, budowania i aktywnego kształtowania kultury zrównoważonego rozwoju. Działania innych aktorów sceny społeczno-politycznej, aczkolwiek występuja, to nie mają i nigdy nie będą miały odpowiedniej rangi, jak i właściwej mocy sprawczej. „Niewidzialną" barierą rozwoju Polski nadal jest ta, która wynika z niepełnego wpisania całokształtu kultury zrównoważonego rozwoju do polskiej kultury.

\section{Unijna polityka spójności}

W przeciwieństwie do działania, a expressis verbis niedziałania polskiego systemu instytucjonalnego, szalenie istotny stał się wpływ unijnej polityki spójności na proces recepcji, percepcji i masowego, aktywnego wpisania kultury zrównoważonego rozwoju (sustainable development) do polskiej kultury.

W istocie swojej, w najbardziej syntetycznej definicji unijna polityka spójności polega na wzmocnieniu spójności gospodarczej, społecznej i terytorialnej. Wspólnoty Europejskie przyjęły, że kluczowym, wspólnotowym celem jest zmniejszenie dysproporcji oraz wyrównanie poziomu rozwoju regionów, które tego wymagają w świetle przyjętych kryteriów. Podobnie jak cała istota polityki spójności, kryteria te ulegały i będą ulegać ewolucji, choćby z tego powodu, że nieustannie zwiększa się liczba państw współtworzących Unie Europejska. Tym samym z przyczyn historycznych później dołączające państwa są zdecydowanie mniej rozwinięte od państw założycielskich Wspólnoty. To z kolei, powoduje wzrost regionów wymagający wspomagania wyrównującego.

Szlachta i Zaucha [Szlachta, Zaucha, 2014] w sposób syntetyczny przedstawili ewolucję polityk spójności. Te z poprzednich okresów koncentrowały się na alokacji środków w regionach poniżej wyznaczonych progów PKB. Jednocześnie w roku 2008, w czasie pojawiającego się kryzysu gospodarczego o zasięgu globalnym, europejska polityka spójności została zmodyfikowana w trakcie okresu programowania dzięki wprowadzeniu mechanizmów antykryzysowych. Rzeczywistość otaczająca to globalny system, w którym toczą się różnorakie procesy determinowane zarówno gospodarczo, politycznie, jak i społecznie. Ten wielki system charakteryzuje się tym, że składa się z bardzo wielu podsystemów, a każdy z nich ma pewien własny i odmienny cel działania. Ponadto, występują m.in. liczne liniowe i nieliniowe, bezpośrednie i pośrednie, często odległe w czasie i przestrzeni, ujemne i dodatnie sprzężenia zwrotne. W istocie wszystko jest powiązane ze wszystkim i stąd wynika, że ludzie nie są w stanie poznać przyszłych stanów wielkiego systemu. Ich ograniczone władze poznawcze, metodyczne czy obliczeniowe uniemożliwiają określenie nowych stanów w dalszej przyszłości, a tym samym prognozowanie.

Wnuk-Lipiński stwierdził, że Myślenie o pryysz̨ośsci, nieco bardzৃiej ściste niž intuicja, opiera sie głównie na ekstrapolacjach istniejacych trendów. Ten rodzaj myślenia zakełada, $i$ to w sposób ocrywisty, $i \dot{z}$ tendencje obserwowane w przesz̨ości nie ulegna istotnym zmianom i również w praysžtości przebiegać beda w podobny sposób. Jeśli to zatożenie, na ogót milczaco prayjmowane okaże sie trafne, to prognozy oparte na ekstrapolacjach moga sie sprawdzić. Najcześciej jednak. zatożenie, okaruje sie błedne. Jak wykazuja bowiem doswiadcrenia choćby minionego stulecia, najistotniejsaymi crynnikami ksztaltujacymi przebieg procesów historycznych o dtugich okeresach sa zmiany o charakterze jakoś- 
cionym. Ekstrapolacja trendón jest niezwylkle zawodna wtaśnie z. tego powodu, że dziataja zmiany jakościowe, ketore na ogót przeekraczaja horyzont nyobraźni, uksżtattowany przez doswiadczenia

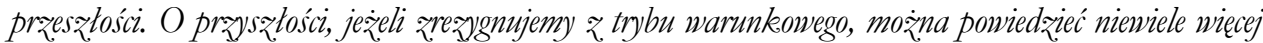
ponad to, że nastanie [Wnuk-Lipiński, 2005]. To samo można powiedzieć o przyszłej polityce spójności Unii Europejskiej w perspektywie jedno- czy kilkupokoleniowej [Szlachta, 2014]. Jednak nie zmienia to faktu, że jej istnienie, nawet w nieznanym kształcie i zakresie, będzie powodowało aktywne zmiany w przestrzeni: terytorialnej, społecznej i gospodarczej Wspólnot Europejskich. Z drugiej strony co najmniej w okresie 2014-2020 będzie to aktywne i twórcze budowanie kultury zrównoważonego rozwoju, zarówno jej niematerialnych aspektów, jak i materialnych. Potwierdza to Rozporz̨qdzenie Parlamentu Europejskiego $i$ Rady (UE) nr 1303/2013 z. dnia 17 grudnia 2013 roku ustanawiajace wspólne przepisy dotyczace: Europejskiego Funduszu Rozwoju Regionalnego, Europejskiego Fundusæu Spotecznego, Funduszu Spójności, Europejskiego Funduszu Rolnego na rzeecz Rozpwoju Obszarów Wiejskich oraz. Europejskiego Funduszu Morskiego i Rybackiego oraz ustanawiajace przepisy ogólne dotyczace: Europejskiego Funduszu Rozwoju Regionalnego, Europejskiego Funduszu Spotecznego, Funduszu Spójności i Europejskiego Funduszu Morskiego i Rybackiego oraz uchylajace rozporzadzenie Rady (WE) nr 1083/2006 [Rozporzqdzenie..., 2013]. Są w nim zawarte poniższe cele i dyrektywy kształtujące zrównoważony rozwój.

\section{Artykut 8.}

\section{Zrównoważony rozwój}

Cele EFSI sq osiagane w sposób zgodny z zasada zrównoważonego rozwoju oraz unijnym wspieraniem celu zachowania, ochrony i poprany jakości środowiska naturalnego, zgodnie z art. 11 i art. 191 ust. 1 TFUE, z. un ₹glednieniem zasady «zaniecrysszczajacy placi».

Państwa czlonkowskie i Komisja zapewniaja, aby wymogi ochrony środowiska, efektywnego gospodarowania zasobami, dostosowanie do żmian klimatu i łagodzenie jej skutków, różnorodność biologiczna, odpornosíc na kleski symiotowe oraz, zapobieganie rysylku $i$ zarzadzanie rysykiem byly promowane podczas pryygotonywania i wdrażania umów partnerstwa i programów. Państwa čztonkowskie dostarczaja informacje na temat wsparcia celów dotyczacych zmian klimatu z. wykoraystaniem metodyki opartej na kategoriach interwencii, obszarach docelowych lub środkach, stosownie dla każdego funduszu. Metodyka ta obejmuje proypisywanie konkretnej wagi wsparciu udzielanemu w ramach EFSI na szcreblu odzwierciedlajacej stopien, w jakim wsparcie takie praycsynia sie do osiagniecia celón tagodzenia $i$ dostosowania do zmian klimatu. Praypisana konkretna waga jest różnicowana w zależności od tego, cayy wsparcie praycsynnia sie w znacznym badź umiarkowanym stopniu do realizacï celów ziniazanych ze zmiana klimatu. Jeżeli wsparcie nie prazycsynia sie do realizacji tych celów lub jest nieznaczne, prazpisuje sie wage równq zeru. W prazpadku EFRR, EFS i Funduszu Spójności prsypisywana waga powinna być swiqzana z, kategoriami interwencij okereślonymi w ramach klasyfikacji prayjetej przez Komisje. W przypadku EFRROW praypisywana waga powinna być zwiqzana z. obszarami docelonymi okereślonymi w rozporzadzeniu w sprawie EFRROW, a w pryypadku EFMR z środkami okereślonymi w rozporzqdzeniu w sprawie EFMR. 
Komisja w drodze aktu wykonawczego określa jednolite warunki dla każdego z. EFSI do celów stosowania metodyki, o ketórej mowa w ustepie drugim. Akt wykonawczy jest prayjety zgodnie z.procedura sprawdzajaca, o której mowa w art. 150 ust. 3.

5.2. Zrównoważony rozwój

1. Państwa członkowskie $i$ instytucje zarzqdzajace na wszystkich etapach wdrażania zapewniaja unzglednienie zrównoważonego rozwoju w ramach EFSI, z. poszanowaniem zasady zrównoważonego rozwoju ustanowionej $w$ art. 3 ust. 3 TUE, jak również obowiqzk.u unzalednienia wymogów ochrony środowiska zgodnie z. art. 11 TFUE oraz zasady "zaniecayszrajacy placi« ustanowionej w art. 191 ust. 2 TFUE.

Instytucje zarzadzajace przez caty okeres trwania programu podejmuja dzialania, aby uniknać skutków interwencïi szkodliwych dla środowiska lub je zmniejszyć $i$ zapewniaja wyniki w postaci korzyśsi netto dla społeczeństwa, środowiska i klimatu. Podejmowane driatania moga obejmować:

a) kierowanie inwestycji w strone najbardziej zasobooszczednych i trwatych opcji,

b) unikanie inwestycji, kéóre moga mieć znaczqco negatywne oddziatywanie na środowisko lub klimat $i$ wspieranie driałań tagodzacych pozostałe skutki,

c) branie pod uwage perspektywy dtugoterminowej pray porównywaniu kosztów całego ,cyklu zycia" alternatywnych wariantów inwestycji,

d) zwiekszanie zastosowania zielonych zamówień publicznych.

2. Państwa członkowskie uwagledniaja potencjat inwestycji realizowanej ze wsparciem EFSI $w$ zakresie tagodzenia zmian klimatu $i$ praystosowania sie do nich, zodnie zart. 8, i zapewniaja, że sq one odporne na skutki takich zmian oraz na kleski żmiołowe, takie jak zwiekszone ryzykeo powodzi, susze, fale upatów, pożary lasów oraz, ekstremalne zdarzenia pogodowe.

3. Inwestycje sq spójne z hierarchia gospodarowania woda zoodna z dyrektywa 2000/60/WE Parlamentu Europejskiego $i$ Rady (7) i skupiaja sie na wariantach zarzqdzania popytem. Alternatywne rozwiazania w zakresie podaży rozważane sa jedynie wówczas, gdy wyczer-

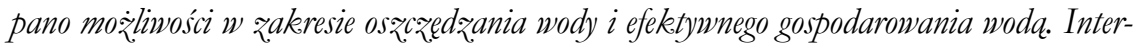
wencja publiczna w sektorze gospodarowania odpadami uzupetnia wysitki podejmowane przez sektor prywatny, w szczególności w odniesieniu do obowiqzków producentów. Inwestycje wspieraja innowacyjne rozwiazania propagujace wysoki poziom recyklingu. Inwestycje sq spójne z bierarchiq postepowania z odpadami ustanowiona na mocy dyrektywy 2008/98/WE Parlamentu Europejskiego i Rady (8). Wydatki zwiazane z różnorodnościq biologiczna i ochrona zasobów naturalnych sa spójne z dyrektywa Rady 92/43/EWG (9).

\section{Artykut 9.}

Cele tematyczne

$W$ celu prayczynienia sie do unijnej strategii na rzecz inteligentnego, zrównoważonego wrostu sprzyjajacego właczeniu społecznemu, jak również realizacji sz̧zególnych zadan funduszy zgodnie z ich celami ok reślonymi w Traktatach, w tym spójności gospodarczej, spotecznej i terytorialnej, każdy EFSI wspiera następujace cele tematyczne:

1) wrmacnianie badań naukowych, rozwoju technologicænnego i innowacji; 
2) zwiekeszenie dostepności, stopnia wykoraystania i jakości TIK;

3) w2macnianie konkurencyjności MŚP, sektora rolnego (w odniesieniu do EFRROW) oraz, sektora rybotówstwa i akwakultury (w odniesienin do EFMR);

4) wspieranie priejscia na gospodarke niskoemisyjna we wsyystkich sektorach;

5) promowanie dostosowania do zmian klimatu, zapobiegania rysylku i zarzadzania rysykiem;

6) zachowanie i ochrona środowiska naturalnego oraz wspieranie efektywnego gospodarowania zasobami;

7) promowanie zrównoważonego transportu i usuwanie niedoborón prępustowości w driatanin najważniejszej infrastruktury sieciowej;

8) promowanie tnwatego i uyssokiej jakośsi zatrudnienia oraz wsparcie mobilności pracownikón;

9) promowanie wtaczenia spotecznego, walka z. ubóstwem i wszelkeq dyskryminacja:

10) inwestowanie w ksztatcenie, szkolenie oraz szkolenie zawodowe na rzecz zdobywania umiejetności i uczenia sie przez całe syccie;

11) w:macnianie zdolności instytucjonalnych instytucji publicznych $i$ zainteresowanych stron oraz sprawności administracii publicznej [Rozporzadzenie..., 2006].

Zacytowane rozporządzenie w sposób jednoznaczny wskazuje, że podobnie jak w poprzednich okresach, działania w ramach unijnej polityki spójności w latach 2014-2020 muszą odnosić się oraz uwzględniać istotę i zasady zrównoważonego. rozwoju. Jest to wartość dodana europejskiej myśli strategicznej w dwudziestym pierwszym wieku.

\section{Determinujące oddziaływanie polityki spójności na polską kulturę zrównoważonego rozwoju}

Kultura zrównoważonego rozwoju stała się osiowym elementem kultury europejskiej, co znajduje swój wyraz zarówno w pracach i dokumentach Komisji Europejskiej, Rady Europejskiej i Parlamentu Europejskiego, jak i innych organów unijnego systemu instytucjonalnego. Oznacza to, że we wszelkie cele działania Unii jako organu jest wpisana istota zrównoważenia (sustensywności), jak i ex definitione mają one być realizowane przez poszczególne kraje członkowskie. Tym samym kultura polityczna Wspólnot Europejskich determinująco oddziałuje na kultury narodowe, w tym kulturę polską, aczkolwiek można explicite stwierdzić, że determinujący czynnik stanowią środki finansowe z budżetu Unii, które są przeznaczone tylko i wyłącznie na działania spełniające zasady zrównoważonego rozwoju.

\subsection{Oddziaływanie strategiczne}

Owo determinujące oddziaływanie polityki spójności znalazło swój wyraz we wszystkich polskich programach operacyjnych na lata 2014-2020 (6 krajowych programów operacyjnych oraz 16 programów regionalnych). Potwierdzają to dwa przykłady, przedstawione poniżej.

1. Zasady zrónnoważonego rozwoju Programu [PO IR - dopisek autora] zostana określone poprzez horyzontalne rozpriazania, takie jak dedykowane nabory na wsparcie projektón majacych pozytywny wplyw na zapewnienie zrónnoważonego rozwoju (np. ekoinnowacje) oraz. 
preferencje punktowe dla projektów z ww. zakeresu w naborach $w$ ramach diatán o ogólnym charakterze (np. wspierajacych projekty $B+R$ przedsiębiorstw) [Program Operacyjny Inteligentny Rozwój na lata 2014-2020, 2014, s. 189].

2. Praktycznym $i$ wymiernym sposobem realizacï zasady zrównoważonego rozwoju w programie operacyjnym [PO IŚ - dopisek autora] bedzie takize opracowanie obiektywnych, zindywidualizowanych na poziomie poszczególnych osi priorytetowych szczegótowych kryteriów wyboru projektów, które beda zatwierdzane przez Komitet Monitorujacy. Przewiduje sie, ze wtaściwie dobrane kryteria pozwola na zapewnienie w praypadku wszystkich przedsiewziéc infrastrukturalnych o charakterze kubaturowym, petnej zgodności ze stosownymi wymogami środowiskonymi oraz dotyczacymi efektymności energetycznej. Jednoczésnie praewiduje sie stosowanie rozwiazań promujacych efektywne wykorzystanie zasobów naturalnych $i$ energii, i pozytywny wplyw na ochrone środowiska również tam, gdzie z. uwagi na specyfike projektów, ich stosowanie nie bedzie miato charakteru obligatoryjnego [Program Operacyjny Infrastruktura i Środowisko na lata 2014-2020, 2014, s. 175].

\subsection{Oddziaływanie operacyjne}

Autor niniejszego artykułu jako ekspert oceniający projekty zgłaszane w ramach: ZPORR, RPO WS i PARP, w latach 2004-2014 musi stwierdzić z całą stanowczą, że zawsze zawierały one odniesienie do kryterium zrównoważonego rozwoju. Potwierdza to przykład, w którym wnioskodawca projektu w ramach Programu Operacyjnego Innowacyjna Gospodarka 4. Oś priorytetowa: Inwestycje w innowacyjne prz̨edsięw zięcia Działanie 4.4: Nowe inwestycje o wysokim potencjale innowacyjnym w odniesieniu do kryterium pozytywny wptyw projektu na środowisko/ zrównoważony rozwój podaje poniższe odniesienie.

Planowany przez. Spótke projekt bedzie miat pozytywny wptyw na polityke zrównoważonego rozwoju, gdyżplanowane rozwiazania pro-środowiskowe pozwola zmniejszyć wplyw na środowisko w stopniu wy ¿̇sym niż wymogi prawa w zakeresie dotyczacym rozmiazan technologicznych prowadzacych do eliminacji szkodliwego oddrialywania na środowisko. Należy podkreśsic, iż drewniane budownictwo prayczynia sie do zmniejszenia $\mathrm{CO}_{2} w$ atmosferze. Zgodnie z danymi opracowanymi przez European

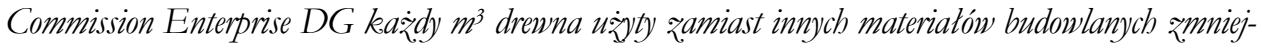
sza średnio o 0,8 tony ilośc $\mathrm{CO}_{2}$ uyemitowanego do atmosfery. Realizacja niniejszego projektu polegajacego na wdrożeniu innowacyjnej technologii wytwarzania nowego w skali swiata produktu [tutaj nazwa proponowanego innowacyjnego produktu wytwarzanego z drewna - dopisek od autora ${ }^{1}$.

Podobnie, w okresie 2014-2020 od projektów, które będą zgłaszane do programów operacyjnych, będzie wymagane odniesienie się do tego kryterium.

\footnotetext{
1 Jest to cytat z ocenianego przez autora wniosku o dofinansowanie realizacji projektu w ramach przytoczonego powyżej programu - działanie: Nowe inwestycje o wysokim potencjale innowacyjnym.
} 


\subsection{Kulturowe i edukacyjne oddziaływanie na polskich aktorów sceny polityczno- -gospodarczej}

Udział bardzo wielu osób we wdrażaniu projektów wynikających z poszczególnych programów operacyjnych, zrealizowanych i obecnie wprowadzanych, oznacza, że ogromna armia aktorów zarówno na scenie polityczno-gospodarczej, jak i społecznej co najmniej pasywnie zetknęła się z terminem zrównoważony rozwój. Innymi słowy, mówi się o procesie pośredniego i trwałego ich edukowania. Urzędnicy ministerialni, w szczególności Ministerstwa Infrastruktury i Rozwoju (uprzednio Rozwoju Regionalnego), podobnie jak i urzędów marszałkowskich oraz gminnych, w sposób permanentny i aktywny mieli do czynienia z ta kategoria. Z kolei, inni aktorzy, jakimi sa przedsiębiorcy, także w tym zakresie byli edukowani. Przynajmniej biernie musieli odnosić się do kryterium zrównoważonego rozwoju, które występowało we wszystkich wnioskach aplikacyjnych o środki w ramach unijnej polityki spójności dostępne w Polsce w ramach RPO.

Tym samym w cieniu polityki spójności wdrażanej w Polsce następował proces edukowania o dużej efektywności i wdrukowywania istoty rozwoju zrównoważonego w kulturę polską. Jednocześnie, już w pełnym świetle, prowadzone były różnorakie szkolenia bezpośrednio związane z eksplikacją tej fundamentalnej kategorii cywilizacyjnej.

\subsection{Merytoryczne kierunkowanie rozwoju}

W rzeczy samej należy wskazać, że cele unijnej polityki spójności umożliwiły wdrażanie wielu mikropragydmatów zrównoważonego rozwoju [Janikowski, 2005]. Jedną z takich kategorii jest ta związana $\mathrm{z}$ rezydualnością po uprzednich aktywnościach człowieka. Przeciwieństwem ich i wynikających wprost $z$ istoty zrównoważonego rozwoju sa:

- rewitalizacja,

- remediacja,

- renaturalizacja,

- restytucja,

- rehabilitacja,

- rekultywacja,

- regeneracja,

- $\quad$ retardacja [Janikowski, 2006; 2013a; 2013b].

Historyczny już, Zintegrowany Program Rozwoju Regionalnego (ZPORR) ma na celu:

- $\quad$ stymulowanie życia społeczno-gospodarczego;

- $\quad$ wzrost potencjału turystycznego i kulturalnego dzięki zapewnieniu wsparcia kompleksowym projektom modernizacji lub budowy infrastruktury;

- $\quad$ wspieranie działań związanych ze zwalczaniem patologii społecznych, tj. przeciwdziałanie zjawisku wykluczenia społecznego.

Był on wdrażany przez realizację projektów, które uwzględniały kompleksowe działania techniczne, takie jak:

- prace renowacyjne, 
- rehabilitacja zabudowy,

- poprawa funkcjonalności dróg oraz infrastruktury dla pieszych,

- $\quad$ wzrost estetyki funkcjonalnej przestrzeni publicznej, w tym renowacja obiektów o wartościach architektonicznych i znaczeniu historycznym zlokalizowanych na rewitalizowanym terenie.

Innymi słowy, od ZPORR aż do obecnie realizowanych PRO następowała materializacja istoty zrównoważonego rozwoju w Polsce, kierunkowana unijną polityką spójności.

\section{Podsumowanie}

Przemiany kulturowe i cywilizacyjne zachodzące we współczesnym świecie są zarazem związane $z$ odmiennym od przeszłego kształtowaniem koncepcji rozwoju. Analizy przeprowadzone w pracy wskazuja, że zarówno czynniki: polityczne, instytucjonalne, edukacyjne, a nawet lingwistyczne, jak i współprzebiegający proces posocjalistycznej transformacji ustrojowej to zasadnicze determinanty, które powodowały i nadal powodują znaczące spowolnienie procesu percepcji i recepcji, a także niedostateczne czy wręcz fałszywe rozumienie idei zrównoważonego rozwoju w Polsce. Jednocześnie zachodzi bardzo korzystny proces wdrażania zasad zrównoważonego rozwoju w Polsce, wywołany przez politykę spójności.

Conditio sine qua non tego, aby koncepcja zrównoważonego rozwoju mogła być w pełni wdrożona, jest jej wdrukowanie w kulturę, która kształtuje nasz sposób kierunkowania rozwoju. Ma zdolność do wprowadzania zmian postaw niezbędnych do zapewnienia zrównoważonego rozwoju. Proces ten już następuje. Jednocześnie przyjęcie aksjomatu, że idea zrównoważonego rozwoju powinna być i już jest osią cywilizacji euroatlantyckiej, przede wszystkim wymaga odpowiednich działań systemu instytucjonalnego państwa.

\section{Literatura}

Baek K. H., Ko N., 2015, Lost in Translation: Problems of Rendering the Term Sustainable Development into Non-Western Languages as Demonstrated in the Case of South Korea, "Problems of Sustainable Development", vol. 10, no. 2.

Ciepiela D., 2014, Piechociński powołat Rade ds. Zrównoważonego Rozwoju Energetyki, 03.10.2014, http://energetyka.wnp.pl/piechocinski-powolal-rade-ds-zrownowazonegorozwoju-energetyki,235429_1_0_0.html (data wejścia: 28.10.2014).

Ekspertyza dotyczqca Edukacji dla Zrównoważonego Rozwoju w Polsce, 2012, Raport Końcowy, Zespół Konsultantów iTTi, Poznań.

ESDN, European Sustainable Development Network, http://www.sd-network.eu/?k= country\%20profiles (data wejścia: 15.07.2015).

Janikowska O., 2007, Challenges and obstacles for the practical implementation of sustainable development in higher education, [in:] Higher Education and the Challenge of Sustainability: Problems, 
Promises and Good Practice, W.L. Fiho, E.I. Manolas, M.N. Sotirakou, G.A. Boutakis (eds.), Environmental Education Center of Soufli, Soufli.

Janikowski R., 2004, Rozwój zrównoważony çy stały?, „Ekonomia i Środowisko”, nr 2 (26).

Janikowski R., 2005, Nieład instytucjonalno-polityczny a trwaty i zrównoważony rozwój, [w:] Zrómnoważony rozwój - doswniadczenia polskie i europejskie, S. Czaja (red.), Biblioteka „Ekonomia i Środowisko”, Nowa Ruda.

Janikowski R., 2005, Paradygmaty trwałego i zrównoważonego rozwoju, „Ekonomia i Środowisko", nr 2 (28).

Janikowski R., 2006, Tereny poprzemystowe a zrównoważony rožwój, „Czasopismo Techniczne. Architektura", z. 8-A.

Janikowski R., 2006, Zrównoważony rožwój jako przzedmiot ksztatcenia ogólnego, [w:] Edukacja dla zrównoważonego rozwoju, T. Borys (red.), Wydawnictwo Ekonomia i Srodowisko, Jelenia Góra-Białystok.

Janikowski R., 2010, Wymiary zrónnoważonego rozwoju. Rozwój lokalny, gospodarka przestrzenna, zdrowie środowiskowe, innowacyjność, Wydawnictwo Wyższej Szkoły Bankowej w Poznaniu, Wrocław-Poznań.

Janikowski R., 2011, Die Bedeutung des Kulturkapitals für nachbaltige Entwicklung, [w:] Nachbaltige Entwicklung - transnational. Sichten und Erfabrungen aus Mitteleuropa, G. Banse, R. Janikowski, A. Kiepas (red.), Edition Sigma, Berlin.

Janikowski R., 2013a, Sustensywne doskonalenie przestrzeni publicznej miasta, [w:] Gospodarka regionalna i lokalna a ro:zuój zrónnoważony, Z. Strzelecki, P. Legutko-Kobus (red.), Studia t. CLII, Komitet Przestrzennego Zagospodarowania Kraju PAN, Warszawa.

Janikowski R., 2013b, Retardacja jako element konceptualizacji rožoju zrównoważonego, „Inżynieria Ekologiczna”, nr 34, s. 5-16.

Jiricka A., Pröbstl U., 2013, The role of SEA in integrating and balancing high policy objectives in European cohesion funding programmes, "Environmental Impact Assessment Review", $38,44-53$.

Juknys R., 2012, Sustainability of Economic and Social Cohesion in the Extended European Union and Possibilities of Sustainable Growth, "Environmental Research, Engineering \& Management", 60(2), 3-4.

Kleiber M., Kleer J., Wierzbicki A.P., Galwas B., Kuźnicki L., Sadowski Z., Strzelecki Z., 2011, Raport Polska 2050, Polska Akademia Nauk - Komitet Prognoz „Polska 2000 Plus", Warszawa.

Korkut U., 2008, Micro and Macro Developments in Hungary Under the Glance of EU Cohesion Funds, "East European Quarterly", 42(3), 285.

Kultura a zrównoważony rozwój. Środowisko, tad przestrzenny, dziedzictwo, 2009, R. Janikowski, K. Krzysztofek (red.), Polski Komitet do spraw UNESCO, Warszawa.

Odpowiedzi Ministra Środowiska Tomasza Podgajniaka - z upoważnienia prezesa Rady Ministrón - na interpelacje nr 10304 (2015) w sprawie driatalności Rady do spraw Zrównoważonego Rozwoju, 2015.

Polska na poczatku XXI wieku: przemiany kulturowe i cywilizacyjne, 2012, K. Frysztacki, P. Sztompka (red.), Polska Akademia Nauk - Komitet Socjologii, Warszawa.

Program Operacyjny Infrastruktura i Środowisko na lata 2014-2020, 2014, MIiR, Warszawa. 
Program Operacyjny Inteligentny Rozwój na lata 2014-2020, 2014, MIiR, Warszawa.

Rozporzadzenie Parlamentu Europejskiego i Rady (UE) nr 1303/2013 z dnia 17 grudnia 2013 roku ustanawiajace wspólne przepisy dotyczqce: Europejskiego Funduszu Rozwoju Regionalnego, Europejskiego Funduszu Społecznego, Funduszu Spójności, Europejskiego Funduszu Rolnego na rzecz. Rozwoju Obszarów Wiejskich oraz Europejskiego Funduszu Morskiego i Rybackiego oraz. ustanawiajace przepisy ogólne dotyczqce: Europejskiego Funduszu Rozwoju Regionalnego, Europejskiego Funduszu Spotecznego, Funduszu Spójności i Europejskiego Funduszu Morskiego i Rybackiego oraz ucbylajace rozporzadzenie Rady (WE) nr 1083/2006, Dz.U. UE L z dnia 20 grudnia 2013 roku.

Szlachta J., 2014, Unijna polityka rozwoju - scenariusze prognoz strategicznych do roku 2050, [w:] Prayszłość wolności. Wymiar krajowy - regionalny - międzynarodowy, A. Kukliński, J. Woźniak (red.), Urząd Marszałkowski Województwa Małopolskiego, Kraków.

Szlachta J., Zaucha J., 2014, Wnioski dla polityki rozwoju regionalnego wynikajace z.polityki spójności Unii Europejskiej, [w:] Wrą̧liwość polskich regionów na wyzwania współczesnej gospodarki. Implikacje dla polityki rozpwoju regionalnego, K. Gawlikowska-Hueckel, J. Szlachta (red.), Oficyna a Wolters Kluwer business, Warszawa.

Traktat z. Liźbony zmieniajacy Traktat o Unii Europejskiej $i$ Traktat ustanawiajacy Wspólnote Europejska podpisany w Lizbonie dnia 13 grudnia 2007 roku, Dz.Urz. UE 2007/C 306/01.

UCLG, 2014, Culture: Fourth Pillar of Sustainable Development, United Cities and Local Governments, Barcelona.

Ustawa z dnia 27 k.wietnia 2001 roku Prawo ochrony środowiska, Dz.U., 2001, nr 62, poz. 627, tekst ujednolicony.

Ustawa z dnia 29 sierpnia 1997 roku o zmianie ustawy o ochronie $i$ ksztaltowaniu środowiska oraz o zmianie niektórych ustaw, Dz.U. 1997, nr 133, poz. 885.

Ustawa z. dnia 31 stycznia 1981 roku o ochronie $i$ ksztaltowaniu środowiska, Dz.U., 1981, nr 3, poz. 6 z późn. zm.

Wnuk-Lipiński E., 2005, Świat międzyepoki. Globalizacja, demokracja, państwo narodowe, Społeczny Instytut Wydawniczy Znak, Kraków.

Zimny A., Zawieja-Żurowska K., 2015, Distance Difficult to Overcome? Analysis of Norwegian and Polish Position on the Path to Sustainable Development, "Problems of Sustainable Development", vol. 10, no. 2. 